\title{
GAMBARAN TINGKAT PENGETAHUAN REMAJA TENTANG HIV/AIDS DI SMA NEGERI 1 BATURITI
}

\author{
Rini Winangsih ${ }^{1,2}$, Kadek Sri Ariyanti ${ }^{1,2}$, Made Dewi Sariyani ${ }^{1,2}$, Ni Made Ayu Swandewi ${ }^{1,2}$ \\ ${ }^{1}$ Program Studi DIII Kebidanan, ${ }^{2}$ Sekolah Tinggi Ilmu Kesehatan Advaita Medika Tabanan \\ Korespodensi penulis: renarafae112@gmail.com
}

\begin{abstract}
Abstrak
Latar belakang dan tujuan: HIV/AIDS merupakan virus yang menyerang kekebalan tubuh manusia. Infeksi virus HIV semakin meningkat bahkan penderita masih dalam usia remaja $(<15$ tahun). Salah satu faktor penyebab adalah kurangnya pengetahuan remaja tentang HIV/AIDS. Data Dinas Kesehatan Provinsi Bali menunjukan bahwa di Kabupaten Tabanan kasus HIV/AIDS sebanyak $6,09 \%$. Tujuan penelitian ini adalah untuk mengetahui gambaran pengetahuan remaja tentang HIV/AIDS di SMA Negeri 1 Baturiti.

Metode: Penelitian ini merupakan penelitian deskriptif. Jumlah sampel dalam penelitian ini 178 siswa. Teknik pengambilan sampel mengunakan cluster sampling. Uji statistik yang digunakan adalah analisa univariat yang menghasilkan distribusi frekwensi variabel.

Hasil: Sebagian besar responden memiliki pengetahuan yang baik tentang kesehatan reproduksi, yaitu sebesar $89,9 \%$. Perlu dikaji lebih dalam sub bagian pengetahuan tentang HIV/AIDS pada penelitian berikutnya, dimana perlu dianalisis apakah dari beberapa sub bagian pengetahuan HIV/AIDS tersebut ada yang kurang dipahami oleh siswa. Selain itu perlu dikaji lebih dalam pula mengenai faktor-faktor yang dapat mendukung peningkatan pengetahuan remaja tentang HIV/AIDS, sehingga dapat ditempuh metode yang terbaik untuk meningkatkan pengetahuan remaja dan dapat membentuk remaja yang disiplin dan bertanggungjawab terhadap kesehatan reproduksinya secara mandiri.

Simpulan: Remaja memiliki pengetahuan baik tentang HIV/AIDS
\end{abstract}

Kata kunci: HIV/AIDS, Pengetahuan, Remaja

\section{Pendahuluan}

Remaja merupakan generasi penerus bangsa sehingga dalam kehidupan perlu mendapat informasi dan pendidikan yang layak baik secara ilmu pengetahuan maupun keagamaan. Pengetahuan yang benar dan pemberian informasi tentang kesehatan reproduksi khususnya HIV/AIDS (Human Immunodeficiency Virus/Acquired Immuno Deficiency Syndrome), sangat penting untuk kehidupan remaja agar tidak terjebak dalam pola kehidupan yang salah (Putro, 2009).

HIV merupakan virus yang memperlemah kekebalan tubuh manusia. AIDS merupakan sekumpulan gejala dan infeksi sindrome yang timbul karena rusaknya sistem kekebalan tubuh. Selain itu
AIDS juga dapat menimbulkan komplikasi penyakit lainnya, seperti penyakit paru-paru, saluran pencernaan, saraf dan kejiwaan, tumor ganas (malignan) dan infeksi oportunistik lainnya. Jika sistem kekebalan tubuh menurun, maka membuat orang tersebut rentan dan mudah terjangkit berbagai macam penyakit infeksi (Sunaryati, 2011).

Menurut data WHO tahun 2012, penemuan kasus HIV di dunia pada tahun 2012 mencapai 2,3 juta kasus, dimana sebanyak 1,6 juta penderita meninggal karena AIDS dan 210.000 penderita Berusia di bawah 15 tahun.

Kasus HIV semakin meningkat di Indonesia pada tahun 2014. Pada 10 tahun 
terakhir ditemukan 206.084 kasus HIV/AIDS yang dilaporkan. Jumlah kasus HIV tertinggi yaitu DKI Jakarta (32.782 kasus), diikuti Jawa Timur (19.249 kasus), Papua (16.051 kasus), Jawa Barat (13.507 kasus), dan Bali (9.337). Data HIV/AIDS berdasarkan usia 15-19 tahun terdapat 1.717 kasus (Kemenkes RI,2014).

Di Provinsi Bali, sampai dengan bulan juni 2017 jumlah kasus yang ditemukan 16.879 yang meliputi 7.094 kasus HIV dan 9.785 AIDS. Kasus HIV/AIDS terbanyak ditemukan di Kota Denpasar sebesar 39,53\% menyusul Kabupaten Badung 16,17\% , Buleleng 15,46\%, Gianyar 7.02\% dan Tabanan memiliki urutan yang kelima $6.09 \%$ kasus. Berdasarkan golongan umur, pada usia 15-19 tahun terdapat 17,32\% kasus (Dinas Kesehatan Provinsi Bali, 2017).

Pada tahun 2015 di Kabupaten Tabanan terdapat 47 kasus HIV yang terdiri dari 22 laki-laki dan 25 perempuan, dengan jumlah kasus AIDS adalah 58 kasus yang terdiri dari 30 laki-laki dan 28 perempuan. Terdapat 2 kasus kematian yang disebabkan AIDS yang keduanya berjenis kelamin laki-laki. Penderita terbanyak pada usia 25-49 tahun yaitu 40 orang sedangkan pada usia 15-19 tahun hanya 1 orang (Dinkes Tabanan, 2015).

Fenomena remaja mengungkap kenyataan bahwa terdapat remaja yang hamil di luar nikah, aborsi, prostitusi, penyebaran video porno dan pengunaan obat-obatan terlarang. Sementara sarana informasi tentang kesehatan pada umumnya dan penyakit menular seksual khususnya HIV/AIDS di beberapa sekolah menegah atas masih kurang, baik itu berupa bacaan yang mendidik maupun penyuluhan dari pihak - pihak terkait (Hasanudin, 2008).

Hal yang menghambat penyampaian informasi ini salah satunya adalah masalah budaya, dimana banyak kalangan yang masih beranggapan bahwa pendidikan seks masih belum pantas dibicarakan remaja baik di lingkungan keluarga maupun lingkungan sekolah, sehingga hal inilah yang menyebabkan kalangan siswa khususnya remaja mendapatkan pendidikan dan pengetahuan yang hanya setengah-setengah.
Informasi yang tidak lengkap ini, akan membuat remaja mencari tahu sendiri dan kurang menyadari akibat yang akan ditimbulkan dari kegiatan tersebut. Selain itu kurangnya peran orang tua dalam kehidupan remaja mengakibatkan banyaknya remaja terjerumus dalam pergaulan bebas yang berisiko maupun narkoba (Hasanudin, 2008).

Berdasarkan survei pendahuluan yang dilakukan di SMA Negeri I Baturiti yang dilakukan terhadap 10 siswa didapatkan hasil, 60\% siswa yang belum mengerti tentang HIV/AIDS, sedangkan $40 \%$ siswa sudah mengerti tentang apa itu HIV/AIDS, penyebab, gejala, cara penularan serta cara pencegahannya. Dalam survei pendahuluan penulis mendapatkan informasi dari bapak wakil kepala sekolah bahwa penyuluhan tentang HIV/AIDS jarang dilakukan di SMA Negeri I Baturiti. Jika ada ada penyuluhan siswa yang khusus mengikuti ekstra PMR dan OSIS yang mengikuti kegiatan tersebut. Oleh sebab itu penulis tertarik melakukan penelitian untuk mengetahui "Gambaran Pengetahuan Remaja tentang HIV/AIDS di SMA Negeri I Baturiti”.

\section{Metode Penelitian}

Penelitian ini merupakan penelitian deskriptif, yaitu metode penelitian yang bertujuan untuk menggambarkan masalah penelitian yang terjadi berdasarkan karakteristik tempat, waktu, umur, jenis kelamin, sosial, ekonomi, pekerjaan, status sosial, pola hidup, dan lain-lain. Populasi yang digunakan dalam penelitian ini adalah siswa kelas XI dan XII berjumlah 319 siswa. Jumlah sampel yang diambil adalah 178 siswa yang diambil secara cluster sampling.

Instrument yang digunakan dalam pengumpulan data berupa kuesioner yang terdiri dari 10 pertanyaan dengan jenis pertanyaan positif dan negatif. Untuk pertanyan postif jika jawaban benar diberi skor 1 dan jawaban salah diberi skor 0 , sedangkan untuk pertanyaan negatif jawaban benar diberi skor 0 dan jawaban salah diberi skor 1.

Kuesioner ini telah dilakukan uji validitas dan reliablitas pada 20 orang siswa 
di SMA Negeri I Marga, sehingga kuesioner ini telah valid dan reliabel untuk digunakan dalam penelitian.

Teknik analisis dalam penelitian ini adalah analisis univariat yang menghasilkan gambaran tentang distribusi dan frekwensi pengetahuan remaja tentang HIV/AIDS.

\section{Hasil dan Pembahasan}

Berdasarkan tabel 1 responden sebagian besar berumur 16 tahun, yaitu sebanyak 77 orang $(43,3 \%)$, berumur 17 tahun sebanyak 76 orang $(42,7 \%)$, sedangkan yang berumur 18 tahun sebanyak 25 orang $(14,0 \%)$. Seluruh responden terbagi ke dalam kelas XI sebanyak 115 orang $(64,6 \%)$ dan kelas XII sebanyak 63 orang $(35,4 \%)$. Responden sebagian besar laki-laki, yaitu sebanyak 95 orang $(53,4 \%)$, sedangkan yang berjenis kelamin perempuan sebanyak 83 orang $(46,6 \%)$.
Dari segi tempat tinggal dapat diketahui bahwa seluruh responden $(100 \%)$ tinggal bersama orang tua. Dilihat dari penghasilan orang tua, sebagian besar siswa penghasilan orang tuanya kurang dari UMK, yaitu sebanyak 97 orang $(54,5 \%)$, sedangkan yang lebih besar dari UMK sebanyak 81 orang $(45,5 \%)$.

Berdasarkan hasil penelitian dapat diketahui bahwa dari 178 responden, hampir seluruhnya $(89,9 \%)$ memiliki pengetahuan baik tentang HIV/AIDS. Persentase yang sangat kecil pada pengetahuan cukup yaitu sebanyak 10 responden $(5,6 \%)$ dan pengetahuan kurang yaitu sebanyak 8 responden $(4,5 \%)$, sehingga dapat disimpulkan bahwa pengetahuan reponden di SMA Negeri I Baturiti termasuk dalam kategori baik.

Tabel 1. Karakteristik Responden

\begin{tabular}{lcc}
\hline Karakteristik Responden & Frekuensi (f) & Presentase (\%) \\
\hline Umur & 77 & 43,3 \\
16 tahun & 76 & 42,7 \\
17 tahun & 25 & 14,0 \\
18 tahun & & \\
\hline Kelas & 115 & 64,6 \\
$\quad$ XI & 63 & 35,4 \\
XII & & \\
\hline Jenis kelamin & 83 & 46,6 \\
Perempuan & 95 & 53,4 \\
Laki-laki & 178 & 100 \\
\hline Tempat tinggal & & \\
Orang tua & 97 & 54,5 \\
\hline Penghasilan orang tua & 81 & 45,5 \\
$\quad<$ UMK & & \\
$>$ UMK & 160 & 89,9 \\
\hline Pengetahuan Remaja & 10 & 5,6 \\
Baik & 8 & 4,5 \\
Cukup & 178 & 100 \\
Kurang & & \\
\hline Jumlah & & \\
\hline
\end{tabular}

HIV adalah virus yang memperlemah kekebalan tubuh manusia. HIV menyerang tubuh manusia dengan cara membunuh atau merusak sel-sel yang berperan dalam kekebalan tubuh sehingga kemampuan tubuh untuk melawan infeksi dan kanker menurun drastis (Sunaryati, 2011).
AIDS adalah sekumpulan gejala dan infeksi sindrome yang timbul karena rusaknya sistem kekebalan tubuh. Selain itu AIDS juga dapat menimbulkan komplikasi penyakit lainnya, seperti penyakit paru-paru, saluran pencernaan, saraf dan kejiwaan, 
tumor ganas dan infeksi oportunistik lainnya (Sunaryati, 2011).

Berdasarkan hasil penelitian dapat diketahui bahwa pengetahuan siswa di SMA Negeri I Baturiti tentang HIV/AIDS sebagian besar dalam kategori baik (89,9\%). Pengetahuan siswa tentang HIV/AIDS dipengaruhi oleh berbagai faktor antara lain faktor internal dan faktor eksternal. Faktor internal terdiri dari umur, jenis kelamin, pendidikan dan pekerjaan. Faktor eksternal terdiri dari faktor lingkungan, sosial budaya, status ekonomi dan sumber informasi.

Faktor-faktor mempengaruhi tingkat pengetahuan remaja tentang HIV/AIDS di SMA Negeri I Baturiti adalah umur, jenis kelamin, penghasilan orang tua. Umur akan sangat berpengaruh terhadap daya tangkap sehingga pengetahuan yang diperolehnya akan semakin baik, Ariani (2014). Dalam penelitian ini sebagian besar berumur 16-18 tahun, dimana mereka sudah memasuki remaja tengah.

Dalam penelitian ini sebagian besar responden yang memiliki pengetahuan baik berjenis kelamin laki-laki yaitu sebanyak $90,5 \%$. Hal ini dikarenakan jumlah laki-laki lebih banyak dibandingkan perempuan. Menurut Ariani (2014), jenis kelamin merupakan faktor yang mempengaruhi pengetahuan, salah satunya adalah adanya perbedaan tingkat kesadaran antara laki-laki dan perempuan serta laki-laki lebih terbuka dalam menerima informasi dibandingkan dengan perempuan.

Penghasilan orang tua juga memiliki pengaruh terhadap pengetahuan. Responden yang memiliki tingkat pengetahuan dalam kategori baik, sebagian besar orang tuanya memiliki penghasilan lebih dari UMK, yaitu sebanyak 91,4\%. Menurut Ariani (2014), Status ekonomi juga akan menentukan tersedianya suatu fasilitas yang diperlukan untuk kegiatan tetentu, sehingga status ekonomi ini akan mempengaruhi pengetahuan seseorang. Penelitian yang dilakukan oleh Kamariyah (2015) yang dilakukan pada siswa kelas XI di SMK Negeri 1 Tegal, menyatakan bahwa sebagian besar penghasilan keluarga responden yaitu
UMR lebih dari Rp. 1.206.000,00, artinya berada dalam keluarga yang mempunyai perekonomian yang cukup. Kemampuan finasial keluarga yang cukup akan mendorong kehidupan yang lebih baik sehingga selalu mencari informasi tentang kesehatan. Hal ini dapat menjadi salah satu faktor yang mempengaruhi tingkat pengetahuan tentang HIV/AIDS.

Penelitian yang dilakukan oleh Maya (2012), yang berjudul Faktor-Faktor yang Mempengaruhi Pengetahuan Siswa-Siswa tentang HIV/AIDS di SMIT Negeri Kota Banda Aceh menunjukan bahwa tingkat pengetahuan siswa-siswi SMIT Negeri Kota Banda Aceh tentang HIV/AIDS sangat berhubungan dengan faktor informasi yang diterima oleh siswa. Semakin baik dan semakin banyak informasi yang diterima, maka akan semakin baik dan mudah siswa tersebut dalam menerima pengetahuan tentang HIV/AIDS begitu pula sebaliknya. Sumber informasi tentang HIV/AIDS sebagaian besar diperoleh siswa melalui penyuluhan.

Penelitian yang dilakukan oleh Benita (2012) di SMP Kristen Gergaji menunjukan bahwa hasil yang didapat melalui pretest tentang kesehatan reproduksi dalam kategori kurang dengan nilai 59\% sedangkan hasil posttest yang didapatkan semakin meningkat menjadi $70 \%$. Dapat disimpulkan bahwa penyuluhan berpengaruh terhadap tingkat pengetahuan kesehatan reproduksi pada remaja di SMP Kristen Gregaji.

Penelitian yang dilakukan oleh Marliyani (2016), di SMA Kharismawita Tanjung Barat Jakarta Selatan Tahun 2016 menunjukan bahwa ada hubungan pengalaman dengan pengetahuan dimana hasil analisis hubungan pengalaman dengan pengetahuan tentang HIV/AIDS diperoleh p-value 0,001 . Hal ini sejalan dengan teori yang dikemukakan oleh Mubarak (2007) bahwa pengalaman merupakan salah satu faktor yang dapat mempengaruhi pengetahuan seseorang.

Peran teman sebaya juga sangat penting dalam pengetahuan remaja tentang HIV/AIDS dimana pada penelitian yang dilakukan oleh Emilwida (2016), di SMA 
Muhammadiyah Sewon Bantul Yogyakarta, yang menunjukan bahwa bahwa ada hubungan peran teman sebaya dengan tingkat pengetahuan kesehatan reproduksi remaja.

\section{Simpulan}

Berdasarkan hasil penelitian yang dilakukan pada 178 responden di SMA Negeri I Baturiti pada bulan Juni-Juli tahun 2018 mengenai tingkat pengetahuan remaja tentang HIV/AIDS dapat di simpulkan bahwa: sebagian besar responden memiliki pengetahuan yang baik tentang kesehatan reproduksi, yaitu sebesar $89,9 \%$.

Perlu dikaji lebih dalam sub bagian pengetahuan tentang HIV/AIDS pada penelitian berikutnya, dimana perlu dianalisis apakah dari beberapa sub bagian pengetahuan HIV/AIDS tersebut ada yang kurang dipahami oleh siswa. Selain itu perlu dikaji lebih dalam pula mengenai faktorfaktor yang dapat mendukung peningkatan pengetahuan remaja tentang HIV/AIDS, sehingga dapat ditempuh metode yang terbaik untuk meningkatkan pengetahuan remaja dan dapat membentuk remaja yang disiplin dan bertanggungjawab terhadap kesehatan reproduksinya secara mandiri.

\section{Referensi}

Ariani, A.P. 2014. Aplikasi Metodologi Penelitian Kebidanan Kesehatan Reproduksi. Yogyakarta: Nuhu Medika.

Benita, 2012. Pengaruh penyuluhan terhadap tingkat pengetahuan kesehatan reproduksi pada remaja siswa SMP Kristen Gergaji. Diakses pada tangga $11-7-2018$

https://www.google.com/search?q=Benita $\% 2$ $\mathrm{C}+2012 .+$ Pengaruh + penyuluhan + terha dap+tingkat + pengetahuan + kesehatan $+r$ eproduksi+pada+remaja+siswa+SMP+ Kristen + Gergaji.\&ie $=$ utf- $8 \&$ oe $=$ utf$8 \&$ client $=$ firefox-b

Dinas Kesatan Provensi Bali, 2017. Situasi Kasus HIV/AIDS di Propinsi Bali pada tahun 2016. Diunduh pada tanggal 19 Juni 2018 dari https://kpa.denpasarkota.go.id/data/Dat
a\%20Kasus\%20HIV\%20AIDS\%20ku mulatif\%201987\%20sampai\%20denga n\%20Tahun\%202016.pdf

Dinkes Tabanan,2015. Data HIV/AIDS di Dinas Kesehatan Kabupaten Tabanan tahun 2015.Diunduh tanggal 10 November 2017 dari http://www.depkes.go.id/resources/do wnload/profil/PROFIL_KAB_KOTA 2015/5102_Bali_Kab_Tabanan_2015.p df

Emilwida, 2016. Hubungan Peran Teman Sebaya dengan Tingkat Pengetahuan Kesehatan Reproduksi Remaja. Diakses tanggal 10 juli 2018 dari http:/ejournal.ijmsbm.org/index.php/ij ms/article/view/80/80

Hasanudin, 2008 dalam Kaliana 2012.Tingkat Pengetahuan Remaja Tentang HIV/AIDS Pada Siswa Kelas XI IPS Di SMA PGRI 1 Karangmalang Sragen Tahun 2012. Diunduh Tanggal 10 November 2017 dari http://digilib.stikeskusumahusada.ac.id/ files/disk1/3/01-gdl-kalinaputr-125-1ktikali-i.pdf

Kamariah, 2015. Gambaran pengetahuan Remaja tentang Keputihan di Kelas XI SMK N I Tegal. Diakses pada tanggal 12 juli 2018 dari http://ejournal.poltektegal.ac.id/index.p $\mathrm{hp} /$ siklus/article/view/412

Kemenkes RI, 2014 dalam Nastiti 2016.Tingkat Pengetahuan Remaja Tentang HIV/AIDS Pada Siswa Kelas XI Dan XII Di SMK Muhammahdiyah 4 Yogyakarta Tahun 2016. Diunduh Tanggal 10 November 2017 dari http://docplayer.info/54577093-

Tingkat-pengetahuan-remaja-tentanghiv-aids-pada-siswa-kelas-xi-dan-xiidi-smk-muhammadiyah-4-yogyakartakarya-tulis-ilmiah-perpustakaan.html

Maya,2012.Faktor-Faktor yang

Mempengaruhi Pengetahuan SiswaSiswa tentang HIV/AIDS. Diakses pada tanggal 10 juli 2018 dari https:journal.uui.ac.id/.../SHINTA_MA YA_SARI-23u-jurnal_shinta_ma... 
Marliyani, 2016. Faktor-faktor yang Berhubungan dengan tingkat Pengetahuan remaja tentang HIV/AIDS. Diakses tanggal 10 juli 2018 dari www.ejournalhealth.com/index.php/t2/ article/download/142/138

Mubarak,I,W. 2012. Promosi Kesehatan Untuk Kebidanan. Jakarta : Salemba Medika

Putro, 2009 dalam Nastiti 2016.Tingkat Pengetahuan Remaja Tentang HIV/AIDS Pada Siswa Kelas XI Dan XII Di SMK Muhammahdiyah 4 Yogyakarta Tahun 2016. Diunduh Tanggal 10 November 2017 dari http://docplayer.info/54577093-

Tingkat-pengetahuan-remaja-tentanghiv-aids-pada-siswa-kelas-xi-dan-xiidi-smk-muhammadiyah-4-yogyakartakarya-tulis-ilmiah-perpustakaan.html

Sunaryati, 2012 dalam Dini 2013.Tingkat Pengetahuan Remaja Tentang HIV/AIDS Pada Siswa Kelas XI Di SMA Negeri 1 Bulu Sukoharjo Tahun 2013. Diunduh Tanggal 10 November 2017 dari http://digilib.stikeskusumahusada.ac.id/ files/disk1/8/01-gdl-diniristan-366-1ktidini-2.pdf

WHO, 2012. Data menurut WHO (World Health Organization) pada tahun 2012 tentang HIV/AIDS . Diunduh pada tanggal 11 November 2017 dari http://eprints.ums.ac.id/28167/2/BAB I_PDF.pd 